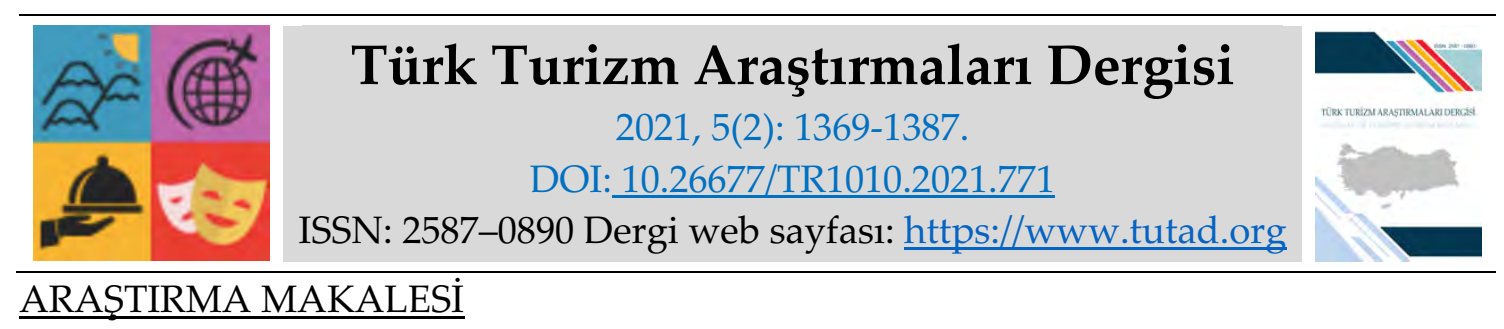

\title{
Turizm ve Festival İlişkisine Yönelik Araştırmaların Bibliyometrik Haritalandırılması (1975-2020)
}

Öğr. Gör. Yasemin AKGÖL, Muğla Sıtkı Koçman Üniversitesi, Datça Kazım Yılmaz Meslek Yüksek Okulu, Muğla, e-posta: yaseminakgol@mu.edu.tr ORCID: https://orcid.org/0000-0001-8733-3673

Doç. Dr. Gökhan AYAZLAR, Muğla Sitkı Koçman Üniversitesi, Turizm Fakültesi, Muğla, eposta: gokhanayazlar@mu.edu.tr ORCID: https://orcid.org/0000-0002-8839-1418

Öz

Bibliyometrik araştırmalar, alanda yapılan çalışmaların incelenmesi ve eğilimlerin ne yöne doğru geliştiğinin anlaşılabilmesi adına araştırmacılara çeşitli faydalar sunmaktadır. Bu çalışmanın amacı turizm ve festival ilişkisine yönelik yapılan araştırmaların bibliyometrik haritalandırmasını yapmaktır. Bu amaca yönelik 1975-2020 yılları arasında Web of Science veri tabanında yer alan dokümanlar taranmıştır. Veri tabanının taranmasında VOSviewer yazılımı kullanılmıştır. Tarama sonucunda turizm ve festival ilişkisini inceleyen 710 çalışmaya ulaşılmıştır. Bu çalışmalar yıl, kaynak dergi, ülke, atıf, anahtar sözcük ve yazar konu başlıklarında değerlendirilmiştir. Elde edilen bulgulara göre turizm ve festival ilişkisini inceleyen çalışmaların sayısında giderek artan bir eğilim görülmektedir. En fazla çalışma Tourism Management dergisinde yayınlamış, en yüksek atıf alan araştırmacı ise Melville Saayman olmuştur. ABD en fazla çalışma yapılan ve en fazla atıf alan çalışmaların yapıldığı ülke olarak görülmektedir. Turizm, festival, etkinlik ve memnuniyet öne çıkan anahtar kelimeleri oluşturmaktadır. Ayrıca turizm ve festival kavramları anahtar kelime, kaynak ve atıflar, ülkeler üzerinden oluşturulan ağ grafikleriyle ele alınarak incelenmiştir.

Anahtar Kelimeler: Turizm, Festival, Web of Science, VOSviewer.

Makale Gönderme Tarihi: 23.03.2021

Makale Kabul Tarihi: 04.06.2021

\section{Önerilen Atıf:}

Akgöl, Y. ve Ayazlar, G. (2021). Turizm ve Festival İlişkisine Yönelik Araştırmaların Bibliyometrik Haritalandırılması (1975-2020), Türk Turizm Araştırmaları Dergisi, 5(2): 1369-1387.

(C) 2021 Türk Turizm Araştırmaları Dergisi. 


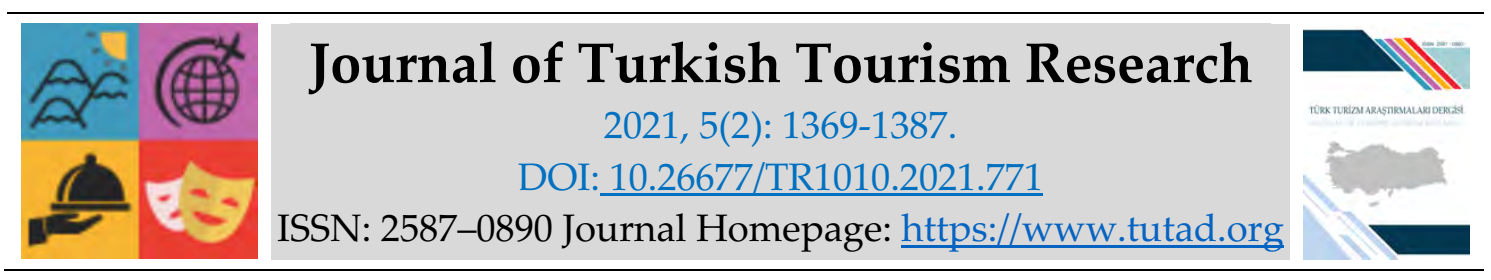

\title{
RESEARCH PAPER
}

\section{Bibliometric Mapping of Research on the Relationship between Tourism and Festival (1975-2020)}

Lecturer Yasemin AKGÖL, Muğla Sıtkı Koçman University, Datça Kazım Yılmaz Vocational School, Muğla, e-mail: yaseminakgol@mu.edu.tr ORCID: https://orcid.org/0000-0001-8733-3673

Associate Prof. Dr. Gökhan AYAZLAR, Muğla Sıtkı Koçman University, Faculty of Tourism, Muğla, e-mail: gokhanayazlar@mu.edu.tr ORCID: https://orcid.org/0000-0002-8839-1418

\begin{abstract}
Bibliometric research offers a variety of benefits to researchers in order to study the research conducted in the field and understand the direction in which trends are developing. The aim of this study is to create a bibliometric map of the research done on the relationship between Tourism and festivals. To fulfill this aim, documents found on the Web of Science database between the years 1975 and 2020 were scanned. VOSviewer software was utilized to scan the database. As a result of the scanning, 710 studies examining the relationship between tourism and festival were reached. These studies were evaluated according to their publication year, source journal, country, citation, keyword, and author. According to the findings, there is an increasing trend in the number of studies examining the relationship between tourism and festival. The highest number of studies were published by Tourism Management magazine, and the most cited researcher was Melville Saayman. The USA has been found to be the country with the largest number of studies and the most cited studies. Tourism, festivals, events, and satisfaction are the prominent keywords. In addition, the concepts of tourism and festival are examined by addressing keywords, sources, and citations with network graphics created over countries.
\end{abstract}

Keywords: Tourism, Festival, Web of Science, VOSviewer.

Received: 23.03.2021

Accepted: 04.06.2021

\section{Suggested Citation:}

Akgöl, Y. and Ayazlar, G. (2021). Bibliometric Mapping of Research on the Relationship between Tourism and Festival (1975-2020), Journal of Turkish Tourism Research, 5(2): 1369-1387.

(C) 2021 Türk Turizm Araştırmaları Dergisi. 


\section{Gíriş}

Festivallerin turizm endüstrisi için ifade ettiği iki ana neden bulunmaktadır (Getz, 2002; Tangita, Kibat ve Adanan, 2016): Birincisi festivaller hayatın sıradanlaşan rutin akışından farklı olarak yeni deneyimler ve anılar sunan güçlü bir seyahat motivasyonu aracıdır. Dolayısıyla hayatına yeni anlamlar katmak isteyen insanların her zaman bir festivalin parçası olabilmek için, sürekli yaşadığı yerin dışına çıkıp, uzak yerlere seyahat etmeye istekli olacakları beklenmektedir. İkincisi festivaller düzenlendikleri destinasyon paydaşlarına önemli ekonomik fayda olanakları sunmaktadır. Festival ziyaretçileri bütçelerine bağlı olarak turizm işletmelerinin ürünlerini tüketir ve hatıra eşyalar satın alırlar. Destinasyona yönelik gerçekleşen para akışı, yeni iş olanakları yaratır ve yöre ekonomisini canlandırır.

Festivaller düzenlendikleri destinasyona ve katılımcılarına faydalar sunan etkili organizasyonlardır. Grappi ve Motanari (2011) bu fayda yönüne vurgu yaparak festivalleri, potansiyel ziyaretçileri çekebilmek için destinasyonlar arasında rekabeti artıran stratejik bir ürün olarak tanımlamaktadır. Destinasyon açısından faydalar ürün çeşitlendirme (Yolal, Woo, Çetinel ve Uysal, 2012), bölge imajını geliştirme (Grappi ve Montanari, 2011), yerel ekonomiyi canlandırma (Felsenstein ve Fleischer, 2003) olarak sıralanırken ziyaretçiler açısından beraberindekilerle birlikte çeşitli deneyim fırsatları (Kim vd., 2010) sunmaktadır.

Karagöz (2006: 43) festivallerin yapılacağı destinasyonlarda birtakım etkiler yaratacağını belirtmiştir. Bu etkiler, ekonomik, sosyo-kültürel, çevresel ve tanıtım pazarlama açısından önemlidirler. Festivallerin ekonomik etkileri, festivale katılan ziyaretçilerin harcamaları, festival düzenlemek için yapılan yatırım giderleri ve festival düzenleyicilerinin yaptığı harcamalar gibi kaynaklarda meydana gelmektedir. Sosyo-kültürel açıdan ele alındığında festivaller, farklı kültürlerin bir araya gelmesiyle birçok insanın etkileşim içinde olması ve ortak bir deneyim yaşaması, yerel halkın sahip olduğu kültür ve değerlere yönelik farkındalık geliştirmesi, sahip çıkması ve bu değerleri koruması, festival yapılan destinasyonlarda sosyal yardımlaşmanın gelişmesi, yeni ve yaratıcı fikirlerin sunulması ve tanıtılması açısından etkilidirler (Gürsoy, Kim ve Uysal, 2004). Fiziksel çevre bakımından ise, çevrenin görsel olarak güzelleştirilmesi, korunması konusunda bilincin arttırılması, bölge alt yapısının iyileştirilmesi ve geliştirilmesi, ulaşım ve haberleşme olanaklarının arttırılması ve bölgenin planlı bir şekilde yenilenmesinin sağlanması olumlu çevresel etkileri oluştururken, atıkların yarattığı kirlilik, gürültü kirliliği, kültürel mirasın tahrip olması ve trafik sorunları olumsuz çevresel etkileri oluşturmaktadır (McDonnell, Allen ve O'Toole, 1999: 20).

Bütün bu olumlu ve olumsuz etkilerin ölçülmesine yönelik önceki araştırmacılar tarafından yapılmış birçok çalışma bulunmakta ve festival konusu günümüzde de araştırmacıların ilgi odağı olmaya devam etmektedir. Ancak yapılan literatür incelemesinde turizm ve festival ilişkisine yönelik bibliyometrik bir çalışmaya ulaşılamamıştır. Yayın ve yazarlara yönelik birçok göstergenin ortaya konması açısından bibliyometrik analiz çalışmaları önem taşımaktadır ( $\mathrm{Al}$, 2008: 265). “Bibliyometrik analiz; belirli bir alanda belirli bir dönemde ve belirli bir bölgede kişiler ya da kurumlar tarafından üretilmiş yayınları ve bu yayınlar arasındaki ilişkileri sayısal olarak analiz eden bir yöntemdir" (Evren ve Kozak, 2014: 67). Bibliyometrik analiz yöntemiyle edinilen bulgular, bilim dallarında alınan yol ve geçirmiş oldukları evrelere dair bilgiler vermekte ve geleceğe yönelik değerlendirmeler yapılmasına olanak tanımaktadır (Şakar ve Cerit, 2013: 38). Bu tür çalışmalar hem literatürde yeterince çalışma olmaması hem de festival temelli turizm faaliyetlerinin olumlu ve olumsuz sonuçlarının ölçülebilir olmasını göstermesi açısından önem taşımaktadır. Dolayısıyla bibliyometri çalışmalarının festival alanında çalışma yapacak araştırmacılar için esinlenebilecekleri bir rehber olarak değerlendirilmesi mümkündür. 
Literatür üzerine yapılan değerlendirmeler ışığında bu çalışma, araştırmacılara turizm ve festival araştırmalarının dinamiklerini daha geniş bir perspektifle inceleme ve anlama imkânı vermek üzere tasarlanmıştır. Buradan hareketle bu çalışmanın amacı, turizm ve festival ilişkisini inceleyen yayınların bibliyometrik haritalandırmasını yapmaktır. Günümüzde Web of Science, Scopus, Google Scholar, PubMed, Medline vb. gibi, bibliyografik veya bibliyometrik araştırmalar yapmada kullanılabilecek çok sayıda veri tabanı bulunmaktadır (Chen, 2017). Bu veri tabanları arasından Web of Science, sosyal bilimler alanında çok sayıda dergiyi kapsamakta ve bibliyometrik haritalandırma yaparak araştırmacılara analiz yapmada büyük kolaylıklar sağlamaktadır. Buna ek olarak, etki faktörü yüksek dergilerin büyük bir kısmının Web of Science veri tabanında taranıyor olması araştırma kapsamında tercih edilme gerekçesi olarak değerlendirilebilir. Ayrıca araştırmacıya verileri elde etmede önemli ölçüde kolaylıklar sağlaması, zengin içerikler sunması dolayısıyla araştırmada Web of Science (WOS) veri tabanı seçilmiştir.

\section{LITERATÜR}

Hayatlarını renklendirmek, değer ve anlam katmak, farklı yerler, toplumlar ve kültürler tanııр yeni bir şeyler öğrenip yeni tatlar tatmak isteyen insanların, bu arayışlarına yönelik bir festival görmek için yaptıkları seyahatler, turizmin gelişimi açısından önemli rol oynamaktadır. Festivaller, katılımcılarına günlük hayatlarında yaşadıklarının dışında farklı deneyimler sunmakta ve hatıralar oluşturmaktadır. Bununla birlikte festivaller, aynı zamanda yapıldıkları şehir, bölge veya ülkeler için iyi bir tanıtım yöntemidir (Tangita, Kibat ve Adanan, 2016: 53).

Festivaller farklı sebeplerle düzenlenseler de düzenlenme amaçları çoğunlukla bölgesel kültürü korumak, tanıtmak, geliştirmek, eğlence ve boş zaman aktivitesi yaratmak, bölge halkına iş imkânı sağlayarak yerel ölçekte turizmi geliştirmektir (Küçük, 2012: 79). Turizm talebi oluşturmak ve turist çekmek konusunda güçlü etkisi olan festivallerin daha önce ifade edildiği gibi birçok faydası bulunmaktadır. Litvin ve Fetter (2006) çalışmalarında bu faydaları, turizm sezonunun tüm yıla yayılması, destinasyon alt ve üst yapısının geliştirilmesi, turizmin çeşitlendirilmesi, destinasyon çekiciliğinin ve bilinirliğinin arttırılması, bölgede yeni yatırımları teşvik etmesi ve destinasyon imajını güçlendirmesi olarak sıralamaktadırlar.

Festivallerin destinasyona etkilerini inceleyen çalışmalarda bu etkilerin genelde olumlu yönleri ele alınsa da olumsuz etkileri de araştırmacılar tarafından incelenmiştir. Yerel halkın sosyokültürel yönden olumlu etkilendiğini gösteren çalışmalarda bu etkiler diğer katılımcılarla etkileşim fırsatı (Dimmock ve Tiyce, 2001), kentsel gurur (Ayazlar ve Ayazlar, 2015), sanat/spor/müzik aktivitelerine katılım (Quinn, 2005; Rowley ve Williams, 2008), toplumsallık duygusu (Derrett, 2003) ve esenlik (Yolal vd., 2016) olarak siralanmaktadır. Bunun yanı sira bazı araştırmacılar (Dimmock ve Tiyce, 2001; Small ve Edwards, 2003) festival süresinde ortaya çıkan araç yoğunluğu, kalabalık ve olumsuz sosyal davranışlarda gözlemlenen artışları festivallerin olumsuz sosyo kültürel etkileri arasında saymaktadırlar.

Festivallerin etkileri düşünüldügüünde ekonomik etkiler aslında neden bu kadar önemsendiklerinin bir göstergesi gibidir. Festivallerin ekonomik etkileri önceki araştırmalarda düzenlendikleri destinasyonda döviz girdisi (Saayman ve Saayman, 2006) vergi gelirlerinde artış (Kim ve Uysal, 2003), yeni iş fırsatları (Compton ve Lee, 2000), yeni istihdam olanakları (Gürsoy, vd., 2004) ve yöre halkının gelirlerinde artış (Yolal, Gürsoy, Uysal, Kim ve Karacaoğlu, 2016) olarak sıralanmaktadır. Festival sürecinde yaşanan olumsuz ekonomik etkiler ise Janeczko vd., (2002) tarafından ürün ve gayri menkul fiyatlarında spekülatif artışlar, turistlere çekici gelmeyen düzenleme maliyetleri, fırsat maliyetleri, yetersiz maliyet tahminleri ve yetersiz yatırım olarak belirtilmektedir. 
Fiziksel çevreye olan etkileri ele alındığında festivallerin olumsuz etkileri daha çok ön plana çıkmaktadır. Ekolojik hasar, doğal sistemin değişimi, mimari kirlilik, kültürel mirasın zarar görmesi ve aşırı kalabalık bu etkilerden ön plana çıkanlarıdır (Gürsoy ve Kendall, 2006; Yolal vd., 2016). Bunun yanı sıra kültürel mirasın korunmasına yönelik girişimler ve yerel alt yapının güçlendirilmesi (Janeczko vd., 2002) ise festivallerin olumlu fiziksel çevre etkileri arasında sayılmaktadır.

Festivaller üzerine yapılan çok sayıda çalışmanın varlığı ve halen daha araştırmacıların ilgi odağında olması, konunun bibliyometrik açıdan ele alınmaya uygun olduğunu göstermektedir. Birçok makale çeşitli disiplinlerde bibliyometrik çalışmalar sunmuştur. Özellikle turizm üzerine Vosviewer ile yapılan araştırmalar, ağırlama ve ağırlama yönetimi (Mulet-Forteza, GenovartBalaguer, Merigo ve Mauleon-Mendez, 2019; Merigo, Mulet-Forteza, Carles, Valencia, Lew, 2019), sorumlu turizm (Segui-Amortegui, Clemente-Almendros, Medina ve Gala 2019), temel sportif etkinliklerin turizme etkileri ve inovasyon (Chamberlain, Edwards, Lai ve Thwala, 2019), turizmde kalite, destinasyon ve tüketici algısı (Garrigos-Simon, Narangajavana-Kaosiri ve Narangajavana, 2019), paylaşım ekonomisi (Sainaghi, Koseoglu, d'Angella ve Mehraliyev 2019) sürdürülebilirlik, iklim değişimi, sağlık ve yeşil ekonomi (Niñerola, Sanchez-Rebull ve Hernandez-Lara, 2019) konularındadırlar.

Ayrıca uluslararası literatürde turizm araştırmalarıyla ilgili çok sayıda bibliyometrik çalışmalar bulunmaktadır. Bunlardan kimileri bibliyometrik analizlerini en etkili dergiler üzerine yapmişlardır (Hall, 2011; Ruhanen, Weiler, Moyle ve McLennan, 2015; García-Lillo, ÚbedaGarcía ve Marco-Lajara, 2016; Omerzel, 2016; Strandberg, Nath, Hemmatdar ve Jahwash, 2018). Jamal, Smith ve Watson (2008), turizm çalışmalarında dergi sıralaması ve alıntıların eleştirel bir analizini sunmaktadır. Goran, Svairi ve Einarsen (2009), turizm ve otelcilik dergilerinin ampirik özelliklerini incelemişlerdir. Kimi yazarlar da turizm dergilerinde yayınlanan konulara odaklanmışlardır (Cheng, Li, Petrick ve O' Leary, 2011; Ruhanen, Weiler, Moyle ve Mclennan, 2015; Köseoğlu, Sehitoğlu, Ross ve Parnell, 2016; Jiménez-Caballero ve Molina, 2017; Okumuş, Köseoğlu, Putra, Doğan ve Yıldız, 2019). Serrano, Sianes ve Ariza-Montes (2019) VOSviewer programını kullanarak sürdürülebilir turizm alanındaki çalışmaların bibliyometrik analizini yapmışlardır. Köseoğlu, Rahimi, Okumuş ve Liu (2016), 1976 ve 2016 yılları arasında konukseverlik ve turizmde gastronomi alanındaki araştırmaların evrimini analiz etmişlerdir. Bazı çalışmalar da en etkili yazarların yayın sayısını incelemiştir (McKercher, 2008; Benckendorff ve Zehrer, 2013; Figueroa-Domecq, Pritchard ve Segovia-Pérez, 2015). Hodak ve Krajinovic (2020) turizmde paylaşım ekonomisi alanında yapılan son araştırmaların incelenmesine yönelik bibliyometrik bir analiz yapmış ve turizm sektöründe paylaşım ekonomisinin gelişimini ve önemini ortaya koymaya çalışmışlardır. Köhler, Digiampietri ve Almeida (2019) çalışmalarında turizm alanında işbirliği ve ortak yazarlık modelini incelemiş ve 14 Brezilya ulusal bilimsel dergisinde 1990-2016 yılları arasında yayınlanan turizm konulu makalelere bibliyometrik analiz yapmışlardır. Liu ve Li (2020)'nin ekoturizmin gelişimini incelemeyi amaçladıkları bibliyometrik araştırmalarında, 1990-2016 yılları arasında Science Citation Index, Social Science Citation Index, Arts and Humanities Citation Index ve Index to Scientific and Technical Proceedings veritabanlarında ekoturizm konusunda yapılan akademik çalışmaları incelemişlerdir. Engelli turizm üzerine bibliyometrik analiz yapan Cunalata, Rosero ve Avila (2021) Science Direct ve Scopus veritabanlarında bulunan, 2008 ile 2019'un ilk yarısına kadar olan dönemde engelli turizmi konusunda yapılmış akademik çalışmalar üzerinde durmuşlardır. De Santana, Maracaja ve Machado (2021) kültür turizmi ve turizm sürdürülebilirliğine yönelik bibliyometrik çalışmalarında, kültür turizmi sürdürülebilirliğinin büyüme eğilimlerini incelemek amacıyla 
2015-2019 yılları arasında Web of Science veritabanında yayınlanan akademik çalışmaların bibliyometrik analizini yapmışlardır. Turizm krizleri ve krizlerin destinasyonlar üzerindeki etkilerini inceleyen Duan, Xie ve Morrison (2021), çalışmalarında sosyal bilimler atıf dizini veri tabanında yer alan 1991-2020 yılları arası yayınlanmış turizm krizleriyle ilgili makalelerin bibliyometrik analiz sonuçlarını sunmuşlardır.

Turizm ve festival ilişkisi üzerine yapılan çalışmaların bibliyometrik analizi ile ilgili az sayıda çalışma bulunmaktadır. Boyacıoğlu ve Elmas (2019), 2005 ve 2019 yılları arasında Dergipark Akademik, Google Akademik ve YÖK Ulusal Tez veri tabanlarında turizm ve festival sözcüklerinin birlikte ele alındığ Şen (2019), bibliyometrik analiz yardımıyla etkinlik turizmi çerçevesinde gastronomik etkinlik içerikli çalışmalara yönelik eğilim ve trendleri belirlemeye çalışılmışlardır. Sürme (2020) Gaziantep'te düzenlenen Uluslararası Gaziantep Gastronomi Festivali katılımcıları üzerinde yaptığı araştırmada festival kalitesinin davranışsal niyete etkisini belirlemeye çalışmıştır. Bu çalışma ise uluslararası literatürde turizm ve festival ilişkisini konu edinen yayınları, WOS veri tabanı üzerinden incelemektedir. Çalışmanın bu yönüyle ilgili araştırmacılara uluslararası literatürde önde gelen çalışmaların festival ve turizm ilişkisinin hangi eğilimlerde ele aldığını gösterebilmesiyle katkı sağlaması beklenmektedir. Bu bağlamda 1975-2020 yılları arasında turizm ve festival ilişkisi ile ilgili WOS veri tabanında yayınlanmış dokümanlar incelenmiştir.

\section{YÖNTEM}

Her alanda bilimsel yayınların sayısı son yıllarda büyük artış göstermektedir. Araştırmacılar için zorluk yaratan bu durum, bilimsel alanda yaşanan gelişmelerin hangi yönde olduğunu, alanın dinamikleri ve yapısının nasıl evirildiğini ele alan ve çeşitli filtrelemeler yolu ile en önemli çalışma alanlarının hangileri olduğunu ortaya koyan bibliyometrik yöntemlerin gerekliliğini ortaya koymaktadır (Demir ve Erigüç, 2018: 97). Bilimsel alanlarda yaşanan gelişmeler ile ilgili çok farklı bir bakış oluşturan bibliyometrik yöntemler, araştırmacıyı mikrodan makroya doğru yönlendirmektedir. $\mathrm{Bu}$ da araştırmacıya alanın dinamiklerini daha geniş bir perspektifle inceleme ve anlama imkânı vermektedir (Zupic, 2015).

Bu çalışma 1975-2020 yılları arasında WOS veri tabanında yayınlanmış turizm ve festival ilişkisini inceleyen çalışmaların bibliyometrik haritalandırmasını yapmayı amaçlamaktadır. Bu amaca yönelik olarak 1975-2000 yılları arasında WOS veri tabanında yayımlanan makaleler incelenmiştir. Bu yönüyle çalışma verilerinin nitel araştırma yöntemleri içerisinde yer alan doküman inceleme tekniği ile toplanmıştır. Bowen (2009) doküman inceleme tekniğini mevcut kayıt ve dokümanların analizi ve gözden geçirilmesi olarak tanımlamaktadır. Kozak (2014) ise doküman analizinin dikkat çekici özelliklerini araştırılan konunun geçmişine yönelik derin bilgiye ulaşılması ve dönem içerisinde meydana gelen değişimin analizi olarak ifade etmektedir.

Veri tabanlarının kimileri diğerlerine göre daha avantajlı olabilmektedirler. Turizm ve festival ilişkisine yönelik yayınların incelenmesi için WOS veri tabanı seçilmiştir. WOS dışında Google Akademik ve Scopus veri tabanları da bulunmaktadır. Google Akademik, akademik yayınlara yapılan atıfları bir arada göstermekte ve buna bağlı olarak dokümanlara atıf sayılarını derecelendirme imkânı sunması dolayısıyla avantajıdır. Scopus ise yayınları bölgesel olarak sistematik şekilde sıralayabilmektedir (Alp ve Ünlü, 2019: 218). WOS veri tabanı daha çok sosyal bilimlerin yayın içeriğine sahip olması, en eski atıf veri tabanı olması, zengin bir atıf verisi içermesi ve eski yıllara uzanan bir bibliyografik veri birikimine sahip olmasından dolayı avantajlıdır (Boyle ve Sherman, 2006). Ayrıca dünyada en prestijli atıf indeksleri olan Science Citiation Index (SCI), Social Science Citiation Index (SSCI) Art and Humanities Citiation Index 
(AHCI) ve Emerging Sources Citation Index'i (ESCI) kapsayan bir veri tabanı olarak WOS dünyadaki birçok nitelikli yayına ulaşma şansı vermektedir (Goodman ve Deis, 2005).

Ulusal literatürde de WOS veri tabanının kullanıldığı bazı çalışmalar bulunmaktadır. Alp ve Ünlü (2019) turizm ve suç ilişkisinin bibliyometrik analizine yönelik yaptıkları çalışmalarında WOS veri tabanını kullanmışlardır. Buna gerekçe olarak da WOS veri tabanın sosyal bilimler alanında çok sayıda dergiyi kapsamasını, farklı parametre, histogram ve sıralamalar oluşturabilmesine bağlı olarak Scopus veri tabanından daha güçlü bir veri tabanı olduğunu belirtmişlerdir. Bu bilgiler doğrultusunda WOS veri tabanının üstün avantajlarına dayanarak çalışmada bu veri tabanının içerdiği verilerden yararlanılmıştır. Bu bağlamda çalışmanın araştırma soruları aşağıdaki gibidir:

WOS veri tabanında turizm ve festival ilişkisine yönelik olarak;

$\rightarrow$ Yapılan yayınlar en çok hangi yıllarda yapılmışlardır?

$\rightarrow$ Yapılan yayınların yer aldığı kaynaklar nelerdir ve bu kaynaklara yapılan atıf miktarına göre ağ grafiği nasıl şekillenmektedir?

$\rightarrow$ Hangi ülkelerden yayın yapılmıştır ve ülkelerin atıf miktarına göre ağ grafiği nasıldır?

$\rightarrow$ Yapılan yayınların anahtar sözcükleri nelerdir ve bu sözcüklerin birlikte bulunması durumunun ă̆ grafiği nasıldır?

$\rightarrow$ En çok atıf alan yazarlar kimlerdir ve bu yazarların aldıkları atıf miktarına göre ağ grafiği nasildir?

WOS veri tabanındaki dokümanları incelemek amacıyla 20 Şubat 2020 tarihinde çevrimiçi bir tarama yapılarak 1975-2020 yılları arasında 710 adet dokümana yönelik veriler edinilmiştir. Çalışmanın kapsamı bağlamında WOS veri tabanında konularına göre "turizm" ve "festival" konuları aranmıştır. Bulunan dokümanlar 562 makale, 129 bildiri, 38 kitap bölümü, 18 erken erişim sistemi, 10 inceleme, 8 editör notu, 1 kitap, 1 kitap incelemesi, 1 düzeltme (correction), 1 not olarak sıralanmaktadır. Çalışma alanları çoğunlukla Ağırlama-Eğlence-Spor ve Turizm (409), Yönetim (97), Çevresel Çalışmalar (67), Sosyoloji (52), Ekonomi (40), Disiplinler arası Sosyal Bilimler (39), Coğrafya (29), Yeşil Sürdürülebilir Bilim Teknolojisi (29), Çevre Bilimleri (26) ve diğer alanlardan oluşmaktadır.

Veriler araştırılırken "turizm" ve "festival" anahtar sözcükleri WOS veri tabanına yazılarak “konu”ya göre tarama yapılmıştır. Yapılan aramada yazar adları, yayın yılları, doküman türleri, kaç yayına atıf yapıldığı ve kaç yayın tarafından atıf aldığı, araştırma alanları ve dergi isimleri gibi veriler edinilmiştir. Edinilen veriler, Excel ve Bibliyometrik yazılımlardan VOSviewer programı kullanılarak bulgulara erişilmiştir. VOSviewer bibliyometrik ağların görsel olarak birbirleriyle ilişkilerini şekil ve renklerle sunan bilimsel bir haritalama programıdır. Program kullanıcısı yazar, anahtar kelimelerin birlikte bulunma durumlarının analizini ve atıf ağlarının görsel olarak ortaya konması konusunda birçok bibliyometrik ağ analizi yapabilmektedir. VOSviewer ortak atıf ağlarından yola çıkarak yayınların veya yazarların ilişkisel ağlarını şekilsel olarak sunmaktadır. Verilerin görsel olarak sunumunda kullanılan algoritma VOS (Visualization Of Similarities)tir. VOSviewer esas olarak bibliyometrik ağları analiz etmek için tasarlanmış olsa da aslında her tür ağ verisine dayalı haritalar oluşturmak, görselleştirmek ve keşfetmek için kullanılabilmektedir. VOSviewer, Java programlama dilinde geliştirilmiştir (Van Eck ve Waltman, 2010). VOSviewer benzerliklerin kümelenmesi yöntemini kullanarak özellikle görsel veriyi yüksek kalitede sunma konusunda çok etkilidir. (Sinkovics, 2016). Bu bilgiler doğrultusunda bu çalışmada VOSviewer yazılımı ile ağ haritaları oluşturulmuş, temel araştırma alanları, kaynakları, doküman çeşitleri, dokümanların yayınlandığı ülkeler ve yayınlandıkları yıllar arasındaki bağlar ortaya konulmaya çalışılmıştır. Araştırmada anket, mülakat, görüşme, 
deney veya gözlem gibi onay formu gerektiren veya kişisel verilerin korunmasına yönelik izin gerektiren veri setleri kullanılmadığı için etik kurul raporu sunulmamıştır.

\section{BULGULAR}

\section{Yıllara, Makale Sayıları, Atıflar ve Ülkelere Yönelik Bulgular}

Festival ve Turizm kavramlarının konu kapsamında WOS veri tabanında aranması üzerine edinilen doküman bilgileri 1975-2020 yılları arasında toplam 710 yayın olduğunu göstermiştir. Aşağıdaki tablo 1'de 2013 ve 2018 yıllarında kısmi düşüşler olsa da yıllara göre yayın sayısında devamlı bir artışın olması festival ve turizm ilişkisinin daha popüler hale geldiğini göstermektedir.

Tablo1. Turizm ve Festival Kavramına Ait Dokümanların Yıllara Göre Dağılımı

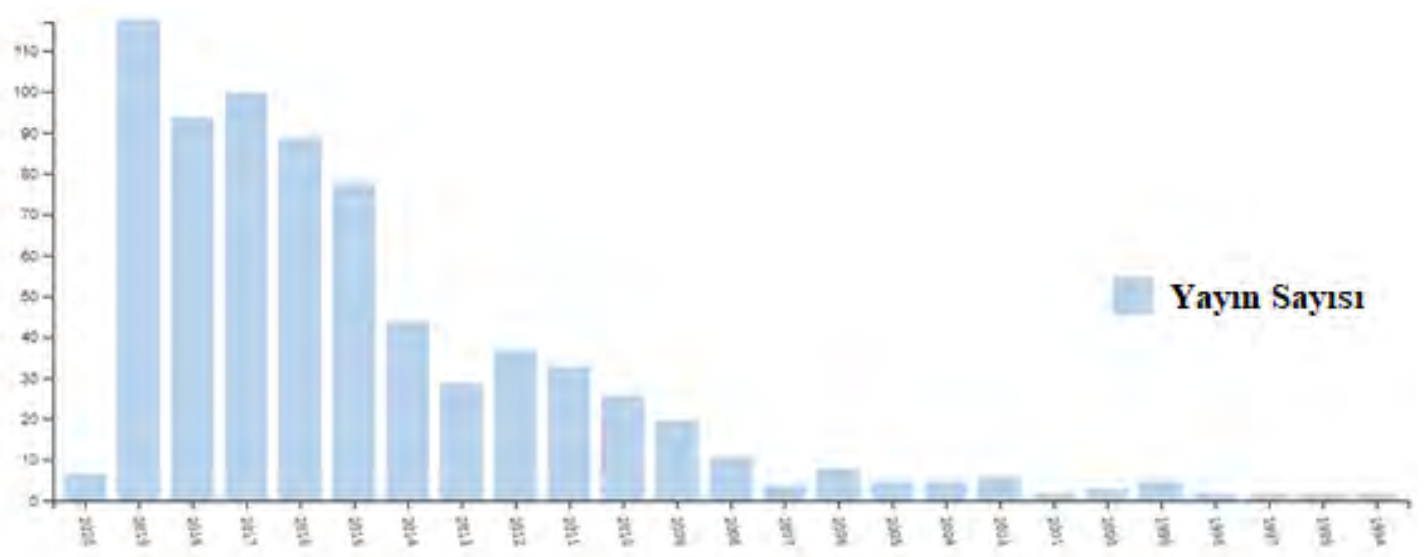

Tablo 1'de yayın yapılan yıllara bakıldığında 117 yayın ile en çok 2019 yılında ve en az yayının da 1992, 1994, 1995, 1997, 1998 ve 2001 yıllarında yapıldığı görülmektedir. Değerlendirmenin yapıldığı 45 yıllık süreçte yayımlanan yayın sayısında dengeli bir dağılım bulunmamaktadır ve yıllık ortalama yayımlanan yayın sayısı 15,7'dir.

Tablo 2. Turizm ve Festival Kavramına Yönelik Dergilerde Kayıtlı Makale Sayısı

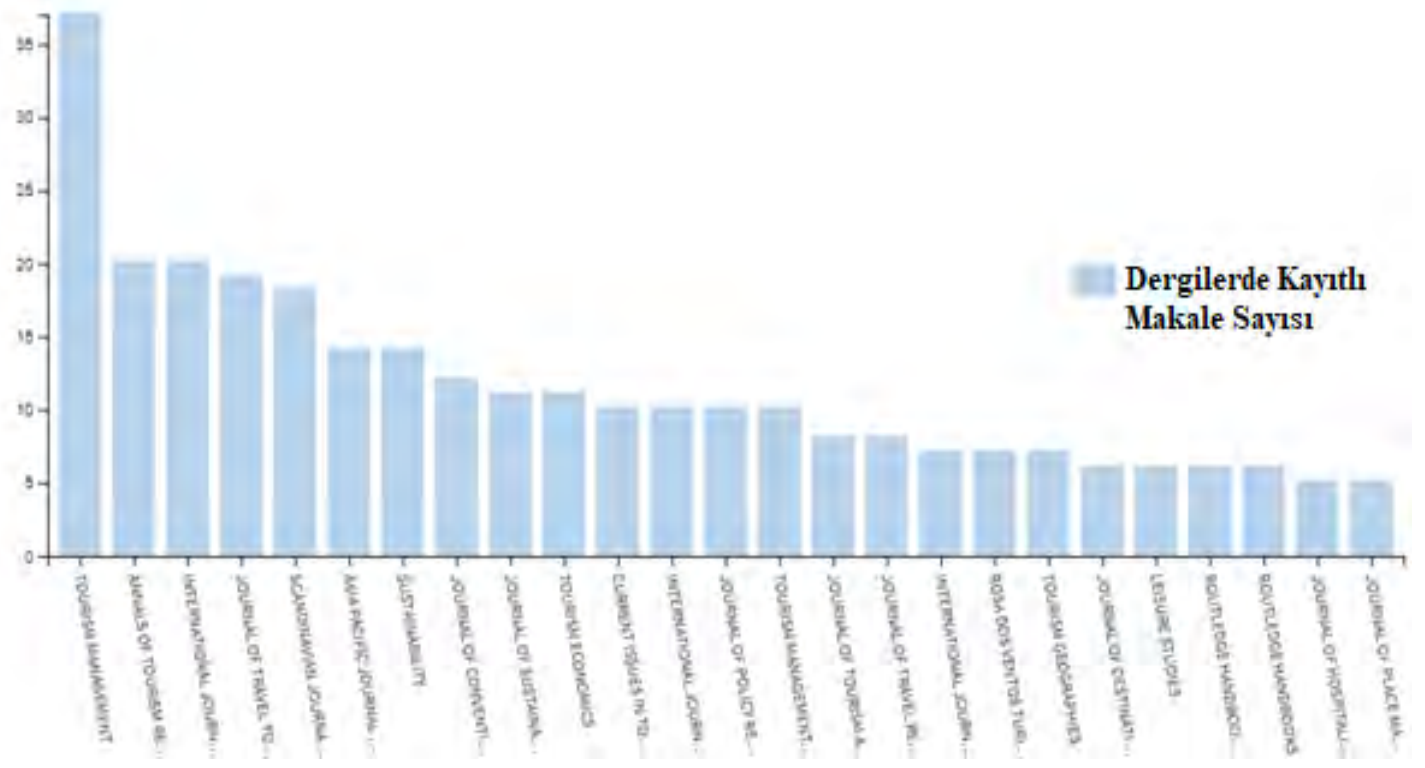


Tablo 2'de görüleceği üzere VOSviewer programı aracılığıyla turizm ve festival kavramlarına yönelik toplam 562 makaleye ulaşılmıştır. Dergilerde kayıtlı makale sayılarına bakıldığında Tablo 2' de de görüleceği üzere makalelerin en çok Tourism Management (37), Annals of Tourism Research (20), International Journal of Event and Festival Management (20), Journal of Travel Tourism Marketing (19) ve Scandinavian Journal of Hospitality and Tourism (18) dergilerinde yayınlandığı görülmektedir.

Tablo 3. Turizm ve Festival Kavramına Yönelik Yayın Kaynakları

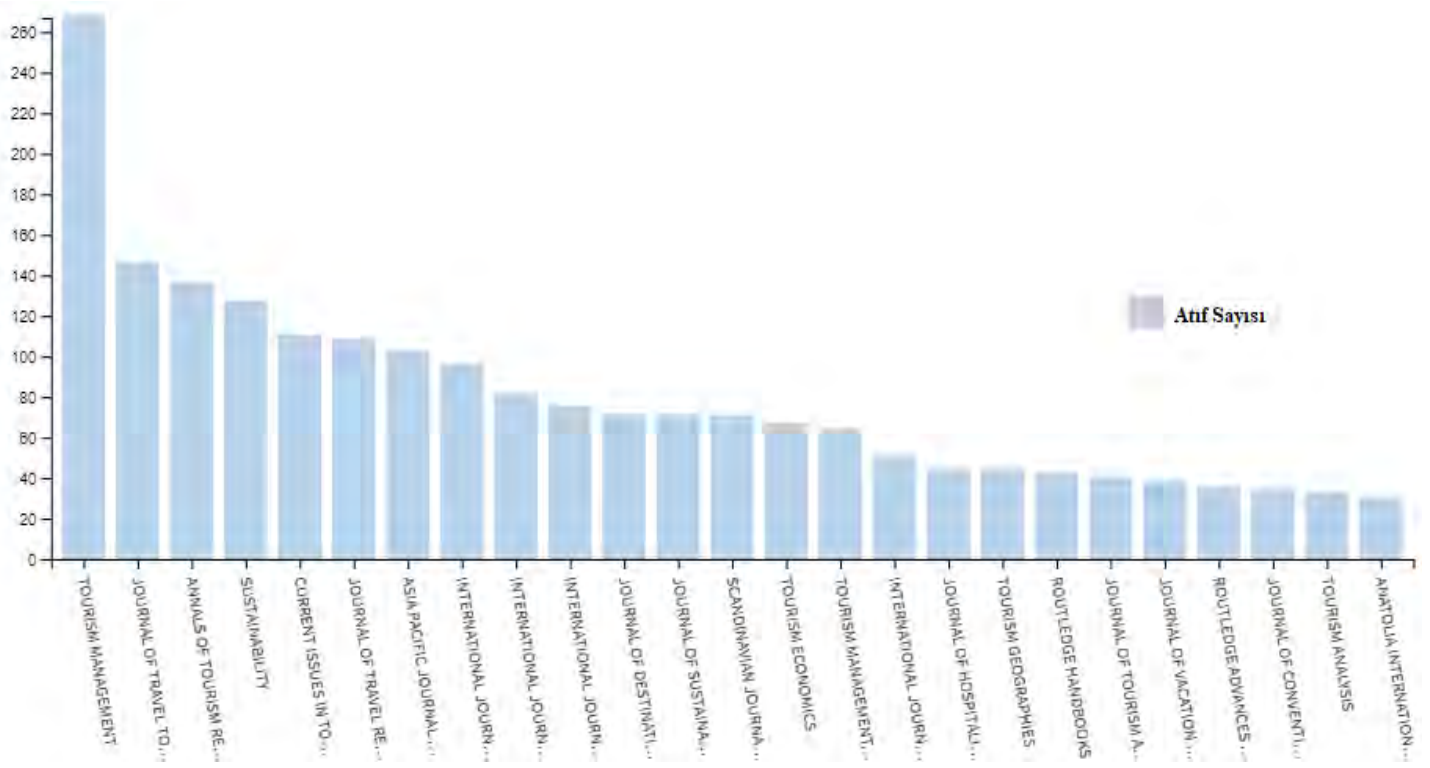

Tablo 3'te yer alan turizm ve festival kavramına yönelik yayın kaynaklarını içeren ve en az 30 atıf sayısına sahip olan dergilere yönelik grafik sunulmuştur. Bu kaynaklar "Tourism Management" (267 doküman), "Journal of Travel Tourism Marketing" (145 doküman), "Annals of Tourism Research" (135 doküman), "Sustainability" (126 doküman), "Current Issues in Tourism" (109 doküman) dir.

Tablo 4. Turizm ve Festival Kavramlarını Araştıran Yazarlara Yönelik Akademik İlgi

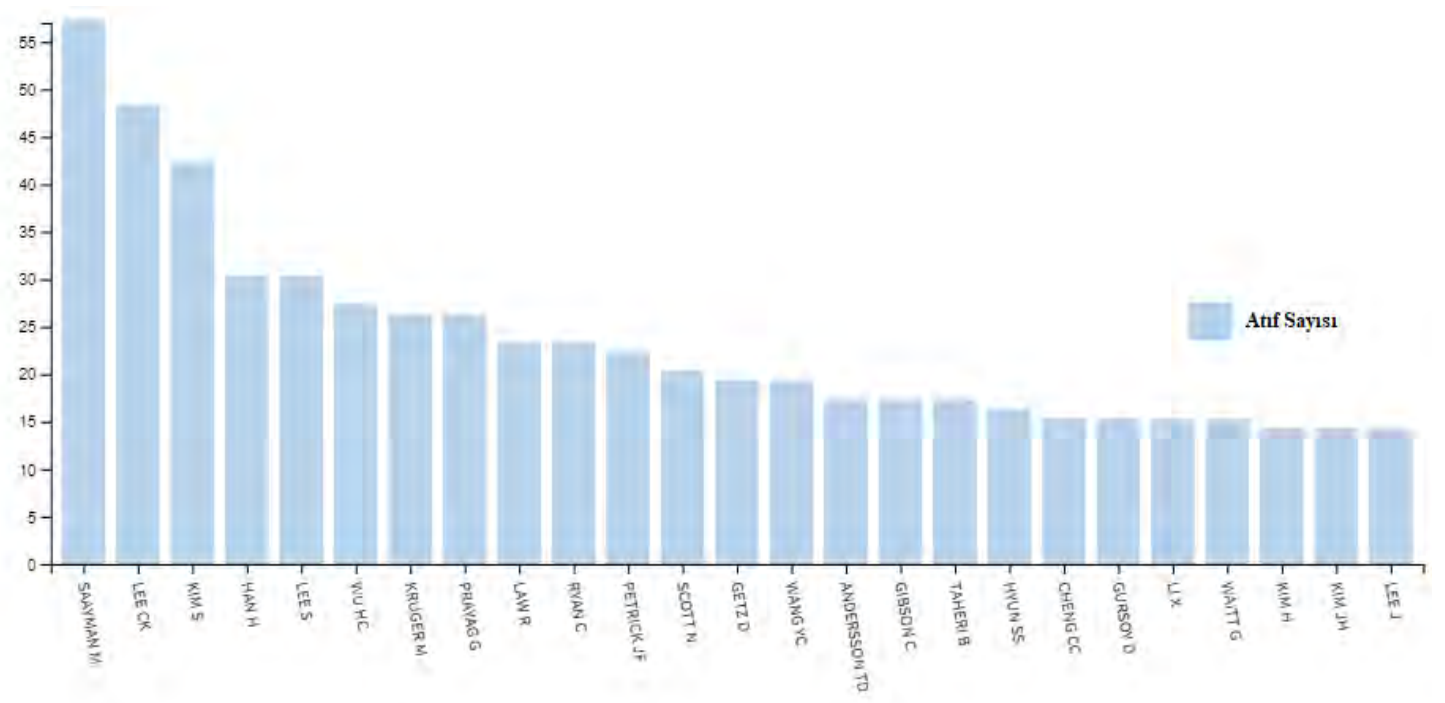


WOS veri tabanında 1975-2020 yılları arasında turizm ve festival kavramları ile ilgili yayını olan yazarlardan en çok atıf alanlar yukarıdaki Tablo 4 'te verilmiştir. Tabloya bakıldığında "Melville Saayman"ın 184 atıfla en fazla akademik ilgi gören yazar olduğu görülmektedir. Saayman dışında yüksek atıf alan diğer yazarlar "Choong-ki Lee", "Seongseop Kim", "Heesup Han", "Sanghyeop Lee" dir.

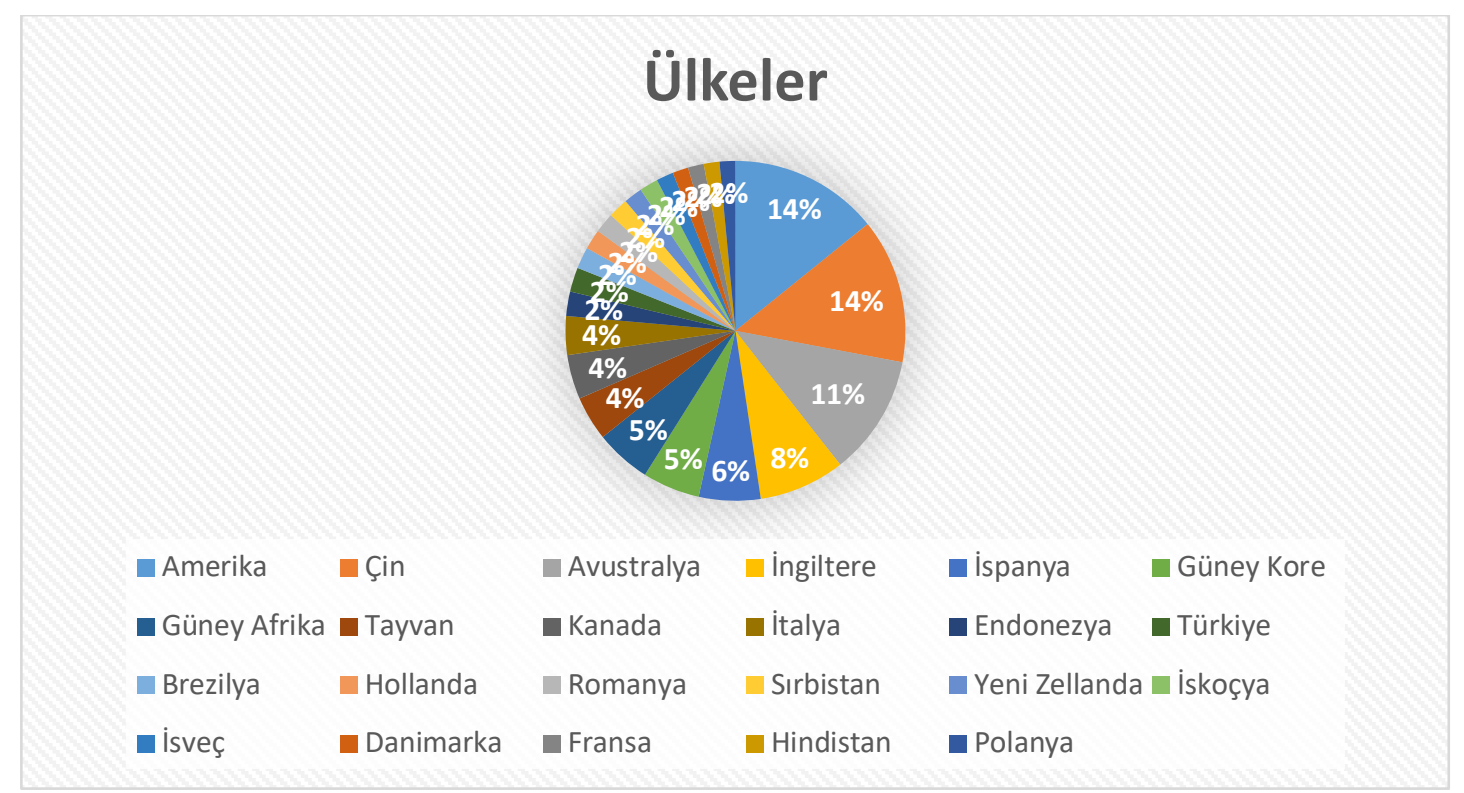

Şekil 1. Turizm ve Festival Kavramlarına Yönelik En Çok Atıf Alan Ülkeler

Yukarıda bulunan Şekil 1'de bulunan pasta grafiğinde, turizm ve festival kavramlarına yönelik sahip oldukları yayınlarla en fazla atıf alan 25 ülke verilen şekilde gösterilmektedir. Şekil 1'de de görüldüğü üzere turizm ve festival kavramlarını içeren en fazla yayına "Amerika Birleşik Devletleri" (104) sahiptir. Amerika'nın ardından Çin (100), Avusturalya (84), İngiltere (60), İspanya (43), Güney Kore (40) ve Güney Afrika (39) gelmektedir.

\section{Turizm ve Festival Kavramlarının Ağ Grafiklerine Yönelik Bulgular}

1975-2020 yılları arasında WOS veri tabanında yayınlanmış olan 710 doküman içinde yazarlar turizm ve festival kavramlarına yönelik toplamda 2221 anahtar kelime belirtmiştir. Bu anahtar kelimeler arasında birlikte bulunma (co-occurrence) veri matrisi VOSvieverde Şekil 2'deki gibi oluşmuştur. Verilen matriste konu ağı ile bir görselleştirme sunulmuş olup toplamda 7 kümeye ayrılmıştır. Kelimelerin birlikteliğine dayanan ağ analizi sonucunda 64 düğümden 286 bağlantı oluşmuştur. Söz konusu düğ̈̈mler turizm ve festival alanında kullanılan yazar anahtar sözcüleri, bağlar ise bu sözcükler arasındaki ilgi durumuna göre bağlantıları ifade etmektedir. 


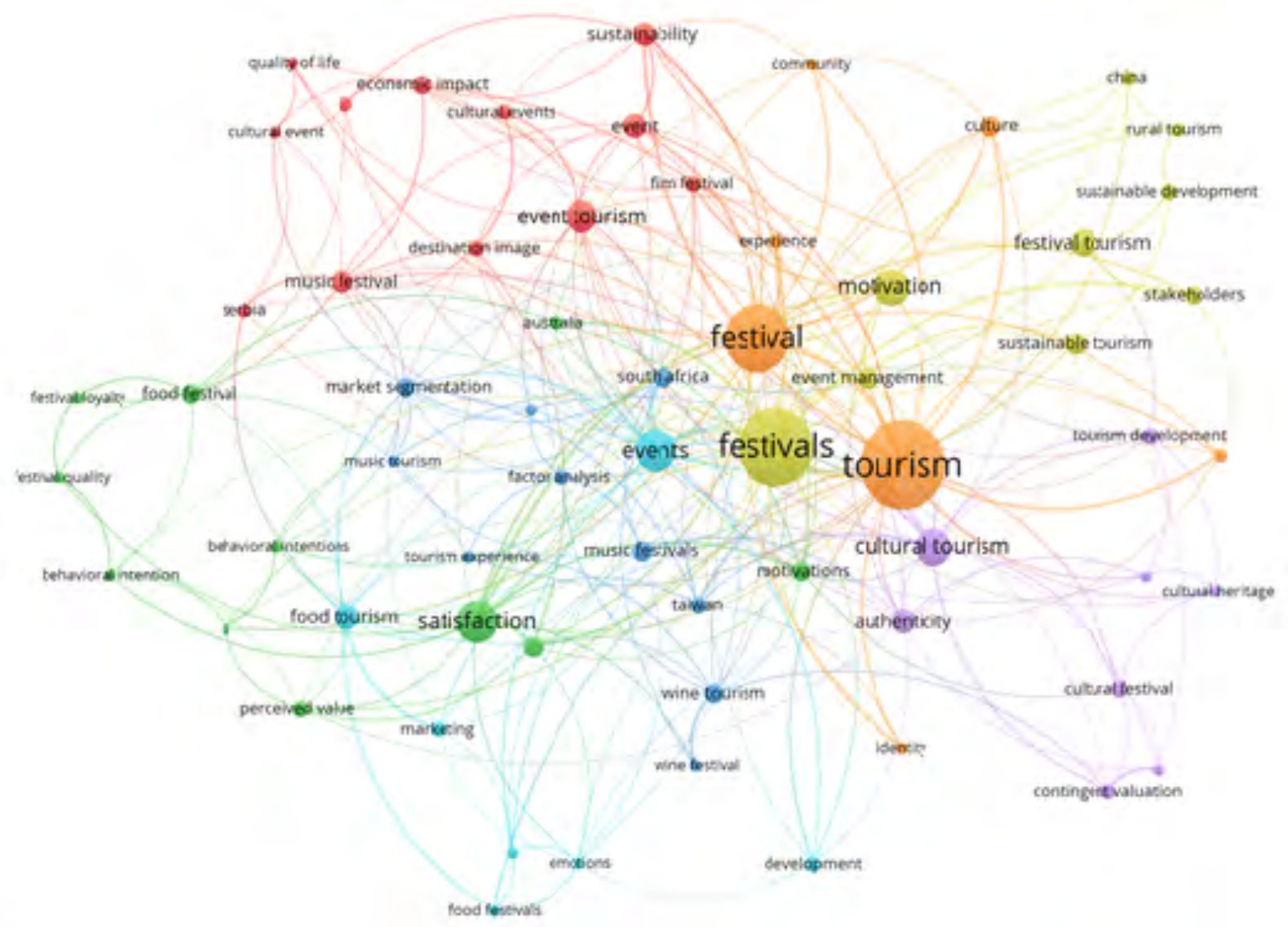

Şekil 2. Turizm ve Festival Kavramlarına Yönelik Anahtar Kelimelerin Bir Arada Kullanılmasına Dair A ğ Grafiğ i

Yukarıda yer alan şekil 2' de de görüldüğü üzere dügü̈mler dairesel yapılıdırlar ve büyüklükleri ilgili anahtar kelimelerin dokümanlarda daha fazla geçtiğini göstermektedir. Yukarıdaki Şekil 2'de yer alan görselin oluşumunda karmaşık bağlantıları sadeleştirmek adına bir anahtar kelimenin en az 5 kez kullanılmış olması koşulu konmuştur. Bu şarttan bağımsız olarak en az 1 kez kullanılan anahtar kelimeler toplamda 2221 dügü̈m iken, en az 5 kez kullanılan anahtar kelimelerle oluşturulan dügüumlerin toplamı $64^{\prime}$ tür. Sonuç olarak kullanım oranı en sık kullanılan anahtar kelimeler değişmemektedir. Şekil 2'de görüleceği üzere en fazla kullanılan bu anahtar kelime 75 kez kullanımla "turizm"dir ve Şekil 2'de de en büyük dairesel merkeze bu anahtar kelime sahiptir. En fazla kullanılan diğer anahtar kelimeler çoğul ve tekil yapılarıyla festivaller (64 kez) ve festival (53 kez) olarak görülmektedir. 10 defadan fazla kullanılan diğer kelimelere baktığımızda bunlar sırasıyla 'etkinlikler', 'memnuniyet', 'kültürel turizm', 'motivasyon', 'etkinlik turizmi', festival turizmi', 'sürdürülebilirlik', 'etkinlik', 'yemek turizmi', 'otantiklik', 'vefa', 'etkinlik yönetimi', 'pazar bölümleme', 'kültür', 'müzik festivali', 'sürdürülebilir turizm' ve 'gastronomi turizmi' dir. Bu kavramlar arasında turizm en çok festival, festivaller, etkinlikler, festival turizmi, motivasyon, memnuniyet, kültür ile bağlantı kurmuştur ve aralarında da en çok 'festivaller'le güçlü bir bağ oluşturmuştur.

Şekil 3'te yazarların atıf alma ağ grafiğini oluşturmak üzere 1975- 2020 yılları arasında WOS veri tabanında turizm ve festival kavramlarına yönelik 710 doküman en az 1 kez kullanılmış olma koşulu ile WOSviever'de arandığında 342 düğümün birbirleriyle bağlantı kurduğu görülmektedir. Bu 342 düğümün 147'si birbirleriyle daha yoğun bir bağ içinde olduğundan Şekil 3'te bu 147 düğüm ve 35 küme ve 562 bağlantiya yönelik görsel sunulmuştur. Şekil 3'de 
görüldüğü üzere en büyük daireler en çok dokümandan atıf alan ve en yüksek bağlantı kuvveti olan kaynakları göstermektedir. Bu bağlamda "Tourism Management" dergisinde yayınlanan bir çalışma 39 farklı kaynaktan toplamda 1646 atıf almıştır. Tourism Management'in ardından 22 farklı kaynaktan 2463 atıf alan "Annals of Tourism Research" kaynağı gelmektedir. Bu iki kaynağın diğer kaynaklarla kıyaslandığında birbirlerine en fazla atıf veren kaynaklarlar olduğu da görülmektedir.

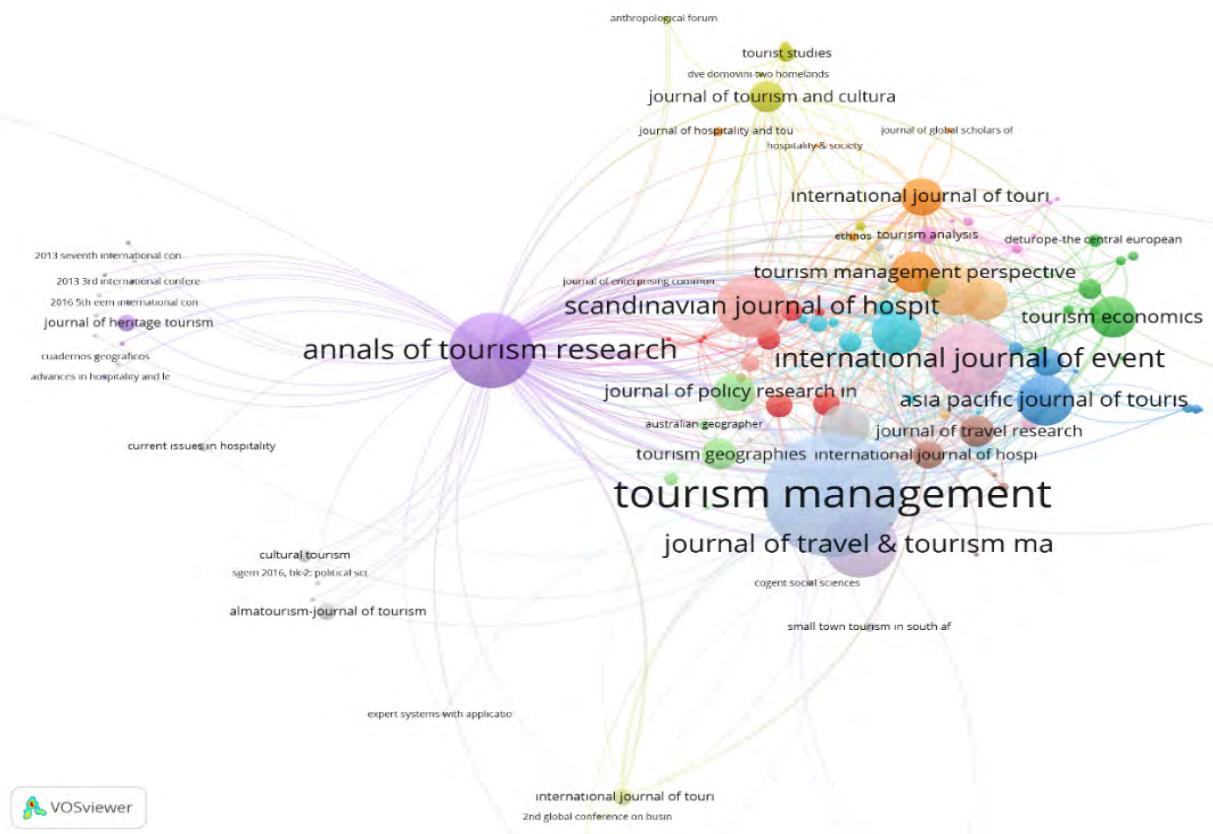

Şekil 3. Turizm ve Festival Kavramlarına Yönelik Kaynak ve Atıfların A ̆̆ Grafiği

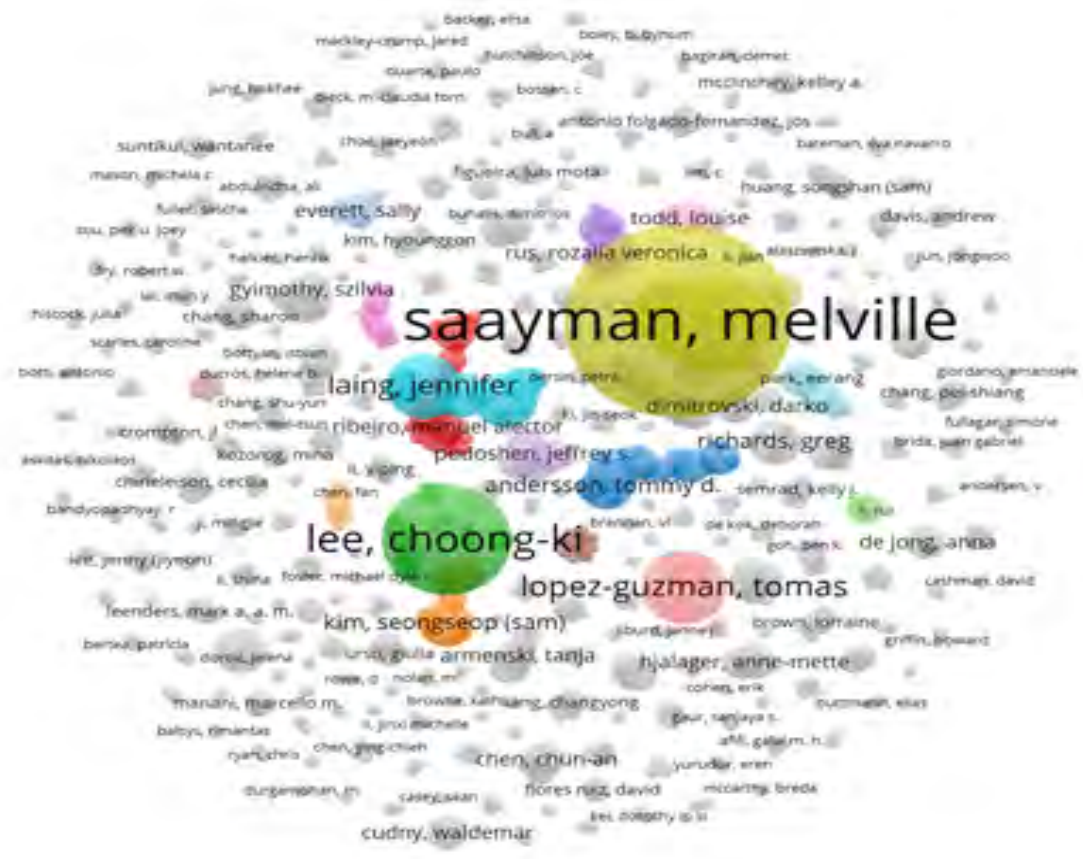

Şekil 4. Turizm ve Festival Kavramlarına Yönelik Yazarların Atıf Alma Durumunun Ağ Grafiği 
WOS veri tabanında turizm ve festival kavramlarına yönelik 710 dokümanın atıf durumuna göre ağ grafiğine baktığımızda yayın sayısı en az 1 ve en az 1 atıf almış yazarları VOSviewer'da Şekil 4'teki gibi görselleşmiştir. Toplamda yazarların 822 dokümanda 287 kümede birbirleriyle 1000 bağlantısı oluşmuştur. Şekil 4'te dairelerin büyüklüğü dokümanlarda ilgili yazarın adının daha çok geçtiğini ifade etmektedir. Şekilde de görüldüğü üzere toplam 21 kaynaktan 184 atıf alarak en geniş dairesel şekilde "Melville Saayman" ve ardından 11 kaynaktan 134 atıf alarak ikinci en geniş dairede "Choong-ki Lee" yer almaktadır.

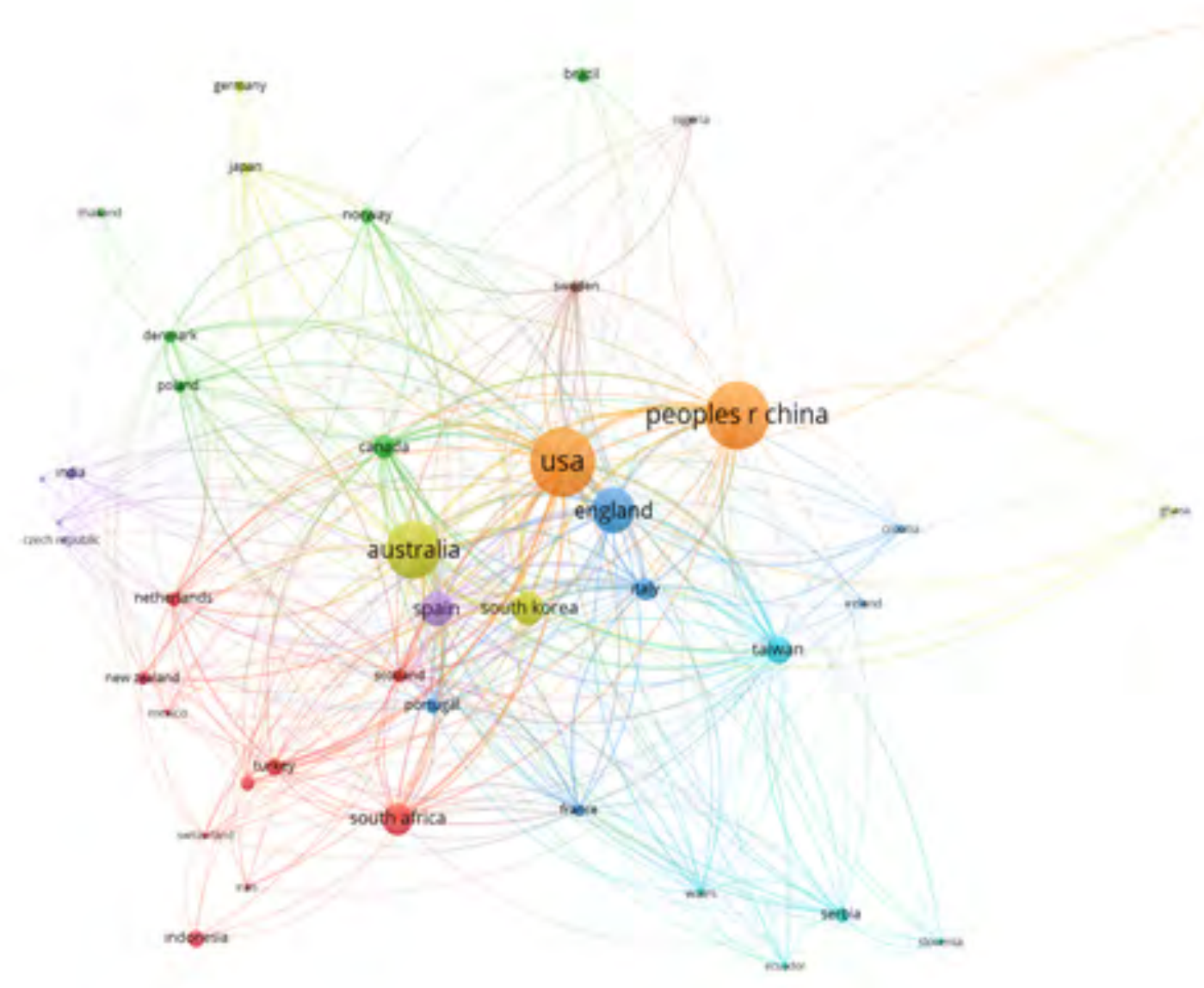

Şekil 5. Turizm ve Festival Kavramlarının Çalışıldığı Ülkelere Yönelik Ağ Grafiği

WOS veri tabanında turizm ve festival kavramlarının çalışıldığı toplam ülke sayısı $74^{\prime}$ tür. Grafiğin daha sade ve anlamlı olabilmesi için her bir ülkenin en az 3 doküman ve en az 1 atıf alma koşulu oluşturulmuş ve bağlı ülke sayısı 42'ye düşmüştür. Toplamda 42 ülkeye ait 9398 atıf, 365 bağlantı ve 8 küme oluşmuştur. A $\breve{g}$ grafiğinde de görüleceği üzere en çok atıf alan ülke 2561 atıfla Amerika Birleşik Devletleridir. Amerika 102 kaynaktan atıf alarak ilk sırada yer alırken onu 101 kaynaktan 369 atıf alan Çin takip etmektedir. Amerika ve Çin dışında Avustralya, İngiltere, Güney Kore, İspanya, Tayvan, Kanada, İtalya, İskoçya, Güney Afrika, Portekiz ve İsveç turizm ve festival kavramlarını içeren çalışmalarıyla en fazla atıf alan ülkelerdir.

\section{TARTIŞMA, SONUÇ ve ÖNERILLER}

Turizm ve festival ilişkisine yönelik bibliyometrik haritalandırma yapma amacıyla gerçekleştirilen bu çalışmada, 1975-2020 yılları arasında WOS veri tabanında turizm ve festival 
ilişkisini inceleyen dokumanlar değerlendirilmiştir. Bu değerlendirme çalışmanın araştırma sorularına cevap vermeye yönelik olarak öncelikle yayın yılları, kaynak dergiler, atıflar üzerinden çokluk-azlık bakış açısıyla tablolar üzerinden yapılmıştır. Daha sonra anahtar kelimelerin bir arada kullanılması, kaynak ve atıfların, yazarların atıf alma durumu ve kavramların çalışıldığı ülkelerin değerlendirilmesine yönelik ağ grafikleri ile gerçekleştirilmiştir.

Yapılan çalışmalar kapsamında turizm ve festival kavramlarının WOS veri tabanında aranması üzerine 1975-2020 yılları arasında toplam 710 doküman olduğu ve 117 yayın ile en çok 2019 yılında en az yayının da 1992, 1994, 1995, 1997, 1998 ve 2001 yıllarında yapıldığı ortaya çıkmıştır. VOSviewer programı aracılığıyla turizm ve festival kavramlarına yönelik toplam 562 makaleye ulaşılmıştır. Dergilerde kayıtlı makale sayılarına bakıldığında makalelerin en çok "Tourism Management" ardında "Annals of Tourism Research" dergilerinde yayınlandığı görülmektedir. Ayrıca "Tourism Management" dergisinde yayınlanan bir çalışmanın 39 farklı kaynaktan toplamda 1646 atıf alması, derginin en fazla atıfa sahip dergi olduğunu göstermektedir.

WOS veri tabanında 1975-2020 yılları arasında turizm ve festival kavramları ile ilgili yayını olan yazarlardan en çok atıf alan yazar "Melville Saayman" ve ardından "Choong-ki Lee" gelmektedir. Ayrıca turizm ve festival kavramlarını içeren dokümanların anahtar kelimelerinde en çok "turizm", "festival", "festivaller" kullanıldığı ortaya çıkmıştır. 10'dan fazla kullanılan diğer kelimelere baktığımızda bunlar 'etkinlikler', 'memnuniyet', 'kültürel turizm', 'motivasyon', 'etkinlik turizmi', festival turizmi', 'sürdürülebilirlik', 'etkinlik', 'gastronomi turizmi', 'otantiklik', 'vefa', 'etkinlik yönetimi', 'pazar bölümleme', 'kültür', 'müzik festivali' ve 'sürdürülebilir turizm' olarak sıralanmaktadır.

WOS veri tabanında turizm ve festival kavramlarının çalışıldığı toplam ülke sayısı 74 'tür. Ülkeler açısından bakıldığında turizm ve festival kavramlarını içeren en fazla yayına "Amerika Birleşik Devletleri" (\%14) ve "Çin"in (\%14) sahip olduğu görülmektedir. Ayrıca en çok atıf alan ülke 2561 atıfla Amerika Birleşik Devletleridir. Amerika 102 kaynaktan atıf alarak ilk sırada yer alırken onu 101 kaynaktan 369 atıf alan Çin takip etmektedir. Amerika ve Çin dışında Avustralya, İngiltere, Güney Kore, İspanya, Tayvan, Kanada, İtalya, İskoçya, Güney Afrika, Portekiz ve İsveç de turizm ve festival kavramlarını içeren çalışmalarıyla en fazla atıf alan ülkelerdir.

Türkiye her ne kadar turizm ve festival kavramlarını çalışan 74 ülke içinde yer alsa da turizm ve festival kavramlarını içeren yayın oranı \%2'lik bir değere sahiptir. Ülkemizde bir yıl içerisinde farklı içeriklere sahip binde fazla festival düzenlendiği (Giritlioğlu, Olcay ve Özekici, 2015) düşünüldügünnde bu oran oldukça düşük olarak değerlendirilebilir. Halbuki ülkemizde düzenlene festival sayısı ve niteliği düşünüldügünde ülke imajını geliştirecek, kültürel dokuyu yansıtacak ve yaşatacak uluslararası çalışmalar için önemli bir potansiyele sahip olduğu değerlendirilebilir. Turizm ve festival kavramlarını WOS veri tabanında çalışan ve bu konuda atıf alan yazar sayımızın artması ile bu potansiyelin kullanılması söz konusu olacaktır.

Turizm ve festival kavramlarını içeren dokümanların anahtar kelimelerinde en çok kullanılan turizm ve festival anahtar kelimeleri dışında etkinlik turizmi, festival turizmi, kültürel turizm, gastronomi turizmi, müzik festivali, sürdürülebilir turizm, otantiklik ve kültür gibi kavramlar da anahtar kelime olarak kullanılmıştır. İleride yapılacak çalışmalarda 'turizm' ve 'festival' kavramlarıla birlikte bahsi geçen diğer anahtar kelimelerin araştırma kavramı olarak ele alınması bu konudaki araştırma sonuçlarını zenginleştirecektir.

Elde edilen bulguların turizm ve festival alanında çalışmayı planlayan araştırmacılar için, literatür taramalarında hangi dergileri taramaları gerektiği, hangi yazarların eserlerinin okunması gerektiği ve kullanacakları ilişkili kavramlar üzerinden yönlendirici bir etkisinin 
olması beklenmektedir. Bu yönlendirmeler literatüre katkı sunmak isteyen araştırmacılar için kritik bilgiler olarak değerlendirilmektedir.

$\mathrm{Bu}$ çalışma WOS veri tabanında yer alan dokümanların incelenmesinden oluşmaktadır. Bu durum çalışmanın temel sınırlılığını oluşturmaktadır. WOS veri tabanında turizm ve festival kavramlarını konusuna göre taranmış ve toplamda 710 dokümana ulaşılmıştır. Turizm ve festival kavramlarına yönelik daha fazla kaynağa ulaşılması açısından ileride yapılacak araştırmalarda SCOPUS gibi veri tabanları da incelenebilir. Farklı veri tabanlarında da yapılacak incelemeye bağlı olarak araştırma genişletilebilir ve sonuçları genelleştirilebilir.

\section{KAYNAKÇA}

Al, U. (2008). Türkiye'nin Bilimsel Yayın Politikası: Atıf Dizinlerine Dayalı Bibliyometrik Bir Yaklaşım, Hacettepe Üniversitesi Sosyal Bilimler Enstitüsü Bilgi ve Belge Yönetimi Anabilim Dalı. Doktora Tezi.

Alp, G. ve Çevik Ünlü, B. (2019). Turizm ve Suç İlişkisinin Bibliyometrik Haritalama ile İncelenmesi. Ömer Halisdemir Üniversitesi İktisadi ve İdari Bilimler Fakültesi Dergisi, 12 (2): 213-228.

Alan, A. ve Şen, Ö. (2019). Gastronomi Temalı Festivaller Üzerine Yapılmış Çalışmaların Bibliyometrik Analizi, 20. Ulusal 4.Uluslararası Turizm Kongresi, Eskişehir. 16-19 Ekim 2019. Eskişehir. ss: 363-373.

Ayazlar, G. ve Ayazlar, R.A. (2015). Festivallerin Sosyal Etkileri ve Kentsel Gurur. İçinde I. Eurasia International Tourism Congress: Current Issues, Trends, and Indicators (EITOC-2015) (ss. 432-444).

Benckendorff, P. and Zehrer, A. (2013). A Network Analysis of Tourism Research. Annals of Tourism Research, (43): 121-149.

Bowen, G. A. (2009). Document Analysis as A Qualitative Research Method. Qualitative Research Journal, 9(2): 27-40.

Boyacıŏlu, E. Z. ve Elmas, Ç. (2019). Turizm ve Festival Olgusunun Bibliyometrik Analizi, 20. Ulusal 4.Uluslararası Turizm Kongresi, Eskişehir. 16-19 Ekim 2019. Eskişehir. ss:111-121.

Boyle, F. and Sherman, D. (2006). Scopus: The Product and Its Development. The Serials Librarian, 49(3): 147-153.

Chamberlain, D. A., Edwards, D., Lai, J. and Thwala, W. D. (2019). Mega event management of formula one grand prix: an analysis of literature. Facilities. 37(13/14), 1166-1184.

Chen, C. (2017). Science Mapping: A Systematic Review of the Literature. Journal of Data and Information Science, 2(2): 1-40.

Cheng, C. K., Li, X., Petrick, J. F. and O'Leary, J. T. (2011). An Examination of Tourism Journal Development, Tourism Management, 32(1): 53-61.

Compton, J. L. and Lee, S. (2000). The economic impact of 30 sports tournaments, festivals, and spectator events in seven US cities. Journal of Park and Recreation Administration, 18(2), 107-216.

Cunalata, G. M., Rosero, D. A. and Avila, M. B. (2021). Turismo accesible: Estudio bibliométrico, Turismo y Sociedad, 28, 115-132. 
De Santana, J. C., Maracaja, K. F. B and Machado, P. D. (2021). Turismo Cultural Y Sostenibilidad Turística: Mapeo Del Desempeño Científico Desde Web of Science. Turismo y Sociedad, (28):95113.

Demir, H. ve Erigüç, G. (2018). Bibliyometrik Bir Analiz ile Yönetim Düşünce Sisteminin İncelenmesi. İş ve İnsan Dergisi. 5(2): 91-114.

Derrett, R. (2003). Festivals \& Regional Destinations: How Festivals Demonstrate A Sense of Community \& Place. Rural Society, 13(1), 35-53.

Dimmock, K. and Tiyce, M. (2001). Festivals and events: celebrating special interest tourism. İçinde N. Douglas, N. Douglas and R. Derrett (Ed.), Special Interest Tourism (ss. 355-383). Milton, Queensland: John Wiley and Sons.

Duan, J.H., Xie, C.W. and Morrison, A. M. (2021). Tourism Crises and Impacts on Destinations: A Systematic Review of the Tourism and Hospitality Literature. Journal of Hospitality and Tourism Research, 20(10): 1-29.

Evren, S. and Kozak, N. (2014). Bibliometric Analysis of Tourism and Hospitality Related Articles Published in Turkey. Anatolia, 25(1): 61-80.

Felsenstein, D. and Fleischer, A. (2003). Local Festivals and Tourism Promotion: The Role of Public Assistance and Visitor Expenditure. Journal of Travel Research, 41(4): 385-392.

Figueroa-Domecq, C. Pritchard, A., Segovia-Pérez, M., Morgan, N. v and e Villacé-Molinero, T. (2015). Tourism Gender Research: A Critical Accounting, Annals of Tourism Research, (52): 87-103.

Garrigos-Simon, F. J., Narangajavana-Kaosiri, Y. and Lengua-Lengua, I. (2018). Tourism and Sustainability: A Bibliometric and Visualization Analysis. Sustainability. 10(6): 1976.

García-Lillo, F., Úbeda-García, M. and Marco-Lajara, B. (2017). The Intellectual Structure of Human Resource Management Research: A Bibliometric Study of the İnternational Journal of Human Resource Management, 2000-2012, The International Journal of Human Resource Management, 28(13), 1786-1815.

Getz, D. (2002), Why Festivals Fail, Event Management, 7(4): 209-19.

Giritlioğlu, İ., Olcay, A. ve Özekici, Y.K. (2015). Bir Turizm Çeşitliliği Olarak Festival Etkinliklerinin Siniflandirilmasi: Türkiye Üzerine Bir Değerlendirme. ODÜ Sosyal Bilimler Araştırmaları Dergisi (ODÜSOBİAD), 5(13), 306-323.

Goodman, D. and Deis, L. (2005). Web of Science (2004 version) and Scopus. The Charleston Advisor, 6(3): 5-21.

Goran, S., Svari, S. and Einarsen, K. (2009). Scientific İdentity' of Scholarly Journals in Hospitality and Tourism Research: Review and Evaluation. International Journal of Hospitality Management. (28): 631-634.

Grappi, S. and Montanari, F. (2011). The role of social identification and hedonism in affecting tourist re-patronizing behaviors: The case of an Italian festival. Tourism Management, (32): 11281140.

Gursoy, D. and Kendall, K. W. (2006). Hosting mega events: Modeling locals' support. Annals of tourism research, 33(3), 603-623. 
Gürsoy, D., Kim, K. and Uysal, M. (2004). Perceived Impacts of Festivals and Special Events by Organizers: An Extension and Validation, Tourism Management, 25(2): 171-181.

Hall, C. (2011). Publish and Perish? Bibliometric Analysis, Journal Ranking and the Assessment of Research Quality in Tourism. Tourism Management. (32): 16-27.

Hodak, D. F. and Krajinovic, V. (2020). Examining recent research in the fi eld of sharing economy in tourism: Bibliometric and content analysis. Tourism: An International Interdisciplinary Journal. 68(4): 402-414.

Jamal, T., Smith, B. and Watson, E. (2008). Ranking, Rating and Scoring of Tourism Journals: Interdisciplinary Challenges and Innovations. Tourism Management. (29): 66-78.

Janeczko, B., Mules, T. and Ritchie, B. W. (2002). Estimating the economic impacts of festivals and events: a research guide (ss. 1-46). Queensland: CRC for Sustainable Tourism.

Jiménez-Caballero, J. L. and Polo Molina, S. (2017). A Bibliometric Analysis of the Presence of Finances in High-Impact Tourism Journals, Current Issues in Tourism, 20(3): 225-232.

Karagöz, D. (2006). Etkinlik Turizmi ve Etkinlik Turizmi Bağlamında Yabancı Ziyaretçi Harcamalarının Ekonomiye Etkisi: Formula 12005 Türkiye Grand Prix 90 Örneği, Eskişehir: Anadolu Üniversitesi Sosyal Bilimler Enstitüsü Turizm İşletmeciliği Anabilim Dalı, Basılmamış Yüksek Lisans Tezi.

Kim, Y. H., Kim, M., Ruetzler, T. and Taylor, J. (2010). An Examination of Festival Attendees' Behavior Using SEM. International Journal of Event and Festival Management, 1(1): 86-95.

Kim, K. ve Uysal, M. (2003). Perceived Socio-Economic Impacts of Festivals and Events Among Organizers. Journal of Hospitality \& Leisure Marketing, 10(3-4), 159-171.

Köhler, A.F., Digiampietri, L. A. and Almeida, G. S. (2019). Padrão de Colaboração e Coautoria No Campo de Turismo: Análises Bibliométricas e de Redes em 14 Periódicos Científicos Brasileiros (1990-2016). Em Questão, 25(2): 117-143.

Küçük, M. (2012). Turizmin Yerel Kalkınmaya Etkisi: Ankara Kızılcahamam Örneği, Yayınlanmamış Yüksek Lisans Tezi, Atılım Üniversitesi, Ankara.

Kozak, M. (2014). Bilimsel Araştırma: Tasarım, Yazım ve Yayım Teknikleri. Ankara: Detay Yayıncılık.

Köseoglu, M. A., Rahimi, R., Okumus, F. and Liu, J. (2016). Bibliometric Studies in Tourism, Annals of Tourism Research, (61): 180-198.

Köseoglu , M. A., Sehitoglu, Y., Ross, G. and Parnell, J. A. (2016). The evolution of business ethics research in the realm of tourism and hospitality: A bibliometric analysis. International Journal of Contemporary Hospitality. 28(8): 1598-1621.

Liu, S. and Li, W. Y. (2020). Ecotourism Research Progress: A Bibliometric Analysis During 19902016. SAGE Open. 10(2): 1-12.

Litvin, S. and Fetter, E. (2006). Can A Festival Be Too Successful? A Review of Spoleto, USA. International Journal of Contemporary Hospitality Management. (18): 41-49.

Mcdonnell, I., Allen, J. and O’Toole. (1999). Festival and Special Event Management, John Wiley \& Sons, Chichester.

Merigo, J. M., Mulet-Forteza, C., Valencia, C. and Lew, A. A. (2019). Twenty Years of Tourism Geographies: A Bibliometric Overview. Tourism Geographies, 21(5): 881-910. 
McKercher, B. (2008). A Citation Analysis of Tourism Scholars, Tourism Management, (29): 12261232.

Mulet-Forteza, C., Genovart-Balaguer, J., Merigó, J.M. and Mauleon-Mendez, E. (2019). Bibliometric structure of IJCHM in its 30 years. International Journal of Contemporary Hospitality Management. 31(12), 4574-4604.

Niñerola, A., Sánchez-Rebull, M.V. and Hernández-Lara, A. B. (2020). Quality Improvement in Healthcare: Six Sigma Systematic Review. Health Policy. 124(4): 438-445.

Omerzel, D. (2016). A Systematic Review of Research on Innovation in Hospitality and Tourism. International Journal of Contemporary Hospitality Management. 28: 516-558.

Okumus, F., Köseoglu, M.A., Putra, E.D., Dogan, I. C. and Yıldız, M. (2019). A Bibliometric Analysis of Lodging-Context Research from 1990 To 2016. Journal of Hospitality \& Tourism Research. 43(2): 210-225.

Quinn, B. (2005). Arts festivals and the city. Urban Studies, 42(5-6), 927-943.

Rowley, J. and Williams, C. (2008). The impact of brand sponsorship of music festivals. Marketing Intelligence \& Planning.26(7), 781-792.

Ruhanen, L., Weiler, B., Moyle, B. D. and McLennan, C. J. (2015). Trends and Patterns İn Sustainable Tourism Research: A 25-Year Bibliometric Analysis, Journal of Sustainable Tourism, 23(4): 517-535.

Saayman, M. and Saayman, A. (2006). Does the location of arts festivals matter for the economic impact?. Papers in Regional Science, 85(4), 569-584.

Sainaghi, R., Köseoglu, M. A., D’Angella, F. and Mehraliyev, F. (2019). Sharing Economy: A CoCitation Analysis. Current Issues in Tourism. (23): 1-9.

Segui-Amortegui, L., Clemente-Almendros, J. A., Medina, R. and Gala, M. G. (2019). Sustainability and Competitiveness in the Tourism Industry and Tourist Destinations: A Bibliometric Study, Sustainability, 11(22): 1-30.

Serrano, L., Sianes, A. and Ariza-Montes, A. (2019). Using bibliometric methods to shed light on the concept of sustainable tourism. Sustainability, 11(24), 6964.

Sinkovics, N. (2016). Enhancing he Foundations for Theorising Through Bibliometric Mapping. International Marketing Review, 33(3): 327-350.

Small, K. and Edwards, D. (2003). Evaluating the socio-cultural impacts of a festival on a host community: a case study of the Australian Festival of the Book. içinde T. Griffin ve R. Harris (Ed.), Proceedings of the 9th Annual Conference of the Asia Pacific Tourism Association (ss. 580-593).

Strandberg, C., Nath, A., Hemmatdar, H. and Jahwash, M. (2018). Tourism Research in the New Millennium: A Bibliometric Review of Literature in Tourism and Hospitality Research. Tourism and Hospitality Research. 18(3): 269-285.

Sürme, M. (2020). Festival Kalitesinin Davranışsal Niyete Etkisini Belirlemeye Yönelik Bir Araştırma. Gaziantep University Journal of Social Sciences, 19 (2), 543-551.

Şakar, G. D. ve Cerit, A. G. (2013). Uluslararası Alan İndekslerinde Türkiye Pazarlama Yazını: Bibliyometrik Analizler ve Nitel Bir Araştırma. Atatürk Üniversitesi İ.I.B.F. Dergisi, 27(4): 37-62. 
Tangita, T.M., Kibat, S.A. and Adanan, A. (2016). Lessons in Managing Visitors Experience: The Case of Future Music Festival Asia (FMFA) 2014 in Malaysia, Procedia Economics and Finance, (37): 52-57.

Van Eck, N. J. and Waltman, L. (2010). Software Survey: Vosviewer, A Computer Program for Bibliometric Mapping. Scientometrics. (84): 523-538.

Yolal, M., Gursoy, D., Uysal, M., Kim, H. L., and Karacaoğlu, S. (2016). Impacts of festivals and events on residents' well-being. Annals of Tourism Research, 61, 1-18.

Yolal, M., Woo, E., Cetinel, F. and Uysal, M. (2012). Comparative Research of Motivations Across Different Festival Products. International Journal of event and Festival Management, 3(1): 66-80.

Zupic, I. (2015). Bibliometric methods in management and organization. Organizational Research Methods, 18(3: 429-472. 